\title{
Exploitation of Biostimulants as an Alternative Strategy to Control Bacterial Rot Diseases of Onion (Allium cepa $\mathbf{L}$.) A.A. Gomah*; M.E. Abdallah**; Samia A. Haroun***; S. Farouk**** and Huda H. Badr* \\ * Bacterial Dis. Res. Dept., Plant Pathol. Res. Inst., A.R.C. Giza, Egypt. \\ ** Plant Pathol. Dept., Fac. Agric., Mansoura Univ., Mansoura, Egypt. \\ *** Botany Dept., Fac. Sci., Mansoura Univ., Mansoura, Egypt. \\ ****Agric. Botany Dept., Fac. Agric., Mansoura Univ., Mansoura, Egypt.
}

R acterial soft rots, commonly caused by Erwinia carotovora 3 subsp. carotovora or Erwinia chrysanthemi, and slippery skin, caused by Burkholderia gladioli subsp. allicola as well as sour skin, caused by Burkholderia cepacia of onion bulbs are among the most serious storage diseases of onion (Allium cepa L.) that lead to great loss in bulbs. In this study some biostimulants; chitosan, seaweed extract and humic acid were in vivo tested on onion plants, to determine their controlling potential against bacterial rot diseases. Application of biostimulants proved to be effective in reducing the bacterial rot in stored onion bulbs. All tested biostimulants increased photosynthetic pigments content in onion leaves and total phenols content in onion bulbs, meanwhile they declined lipid peroxidation and the electrolyte leakage percentage in onion bulbs. As a summary, chitosan, seaweed extract and humic acid could be applied to improve plant growth and stimulate plant defense against diseases in concern. These materials are cheap, available, easy to apply, hazardless and environmentally safe.

Keywords: Chitosan, humic acid, onion and seaweed.

Bacterial rot diseases of onion are among the most serious storage diseases of onion bulbs which may be recognized into at least three distinct forms; basically known as soft rot, caused by Erwinia carotovora subsp. carotovora (Ecc) or E. chrysanthemi $(E c)$; slippery skin, caused by Burkholderia gladioli subsp. allicola (Bga) and sour skin, caused by Burk. cepacia (Bc) (McNab, 2004 and Chaput, 1995). Onion bacterial rots cause significant yield losses (Schwartz and Gent, 2004), thus the need for successful control measure is very utmost urgent.

In view of the hazardous impact of chemical pesticides and other agrochemicals on the ecosystems and human health, the biological or almost natural control of plant diseases as an alternative strategy has received increasing attention in recent years. Among the formulations that can be used in the biological control of plant diseases are the biostimulants which are defined as "materials, other than fertilizers, that promote plant growth when applied in small quantities", and are also referred to as "metabolic enhancers" (Zhang and Schmidt, 1997).

Among the most promising biostimulant oligosaccharides is chitosan (2-amino2 -deoxy- $\beta$-D-glucose), which has attracted tremendous attention because of its 
biocompatibility, non-toxicity and biodegradability. Inhibitory effect on the growth of various pathogens and stimulating plant growth was indicated (Farouk et al., 2008 and 2012) and its ability to be potent elicitor of plant defense reactions was correlated (Sharathchandra et al., 2004).

Chitosan also attracted attention by its great antioxidant activity (Park et al., 2004), it can scavenge $\mathrm{OH}$ and $\mathrm{O} 2$ - radicals and has been shown to have DNAprotection properties (Harish Prashanth et al., 2007). Recently, Sheikha and Al-Malki (2011) indicated that chitosan works as a positive factor in enhancing shoot and root length, fresh and dry weights of shoots and roots as well as leaves area. For some horticultural and ornamental commodities, chitosan increased harvested yield (Bautista-Baños et al., 2006).

Application of seaweed extracts have been proven to have a wide range of beneficial effects on plants such as deeper root development, delay of fruit senescence (Zodape et al., 2008 and 2011), early seed germination and improved crop performance and elevated resistance to biotic and abiotic stress, along with increasing shelf-life of perishable products were considered (Blunden, 1991 and Norrie and Keathley, 2006) as well as plant defense improvement against diseases (Farouk et al., 2012). Brown seaweeds are most commonly used in agriculture (Blunden and Gordon, 1986) especially, Ascophyllum nodosum L., commonly known as Norwegian kelp (Ugarte et al., 2006). Seaweed contains all major and minor plant nutrients, all trace elements, alginic acid, vitamins, cytokinins, auxins, at least two gibberellins and antibiotics. Alginic acid is a soil conditioner, while the remainders are plant conditioners that affect cellular metabolism in treated plants leading to enhanced growth and crop yield (Khan et al., 2009). The exact physiological mechanisms are still not known.

Humic acid can be applied successfully in many areas of plant production as a plant growth stimulant or soil conditioner for improving natural resistance of plant against diseases and pests (Farouk et al., 2012), through stimulating plant growth of nutrients and water (El-Ghamry et al., 2009). Humic acid preparations were reported to promote the root length (Canellas et al., 2002) and increase the fresh and dry weight of crop plants (Chen et al., 2004a and 2004b). Several reports indicated the efficiency of humic acid in reducing some plant diseases, as chocolate spot and rust diseases of faba bean (El-Ghamry et al., 2009), and early blight of tomato (Farouk et al., 2012).

The objective of this study was to evaluate the efficacy of chitosan, seaweed extract and humic acid on controlling onion postharvest bacterial rot and studying some physiological responses of onion plants as a result of the use of these materials.

\section{Materials and Methods}

The pathogenic bacterial strains:

Two isolates of the onion bacterial rot pathogens; Erwinia carotovora subsp. carotovora (Ecc) and Burkholderia cepacia $(\mathrm{Bc})$ were recovered and identified in a previous study by Mansour et al. (2011).

Egypt. J. Phytopathol., Vol. 43, No. 1-2 (2015) 


\section{The tested biostimulants:}

Three biostimulants were used in this study; chitosan (Chito), seaweed extract (SW) and humic acid (HA). The chitosan was produced by ROTH Company, Germany. Chitosan solution was prepared using a modified method of El-Hassni et al. (2004) through dissolving it in $0.25 \mathrm{~N} \mathrm{HCl}$, the $\mathrm{pH}$ was adjusted to 5.6 with 2 $\mathrm{N} \mathrm{NaOH}$. The seaweed extract is an extract from the brown seaweed Ascophyllum nodosum, in form of water soluble paste, produced by Acadian Seaplants Limited Company (Dartmouth, Nova Scotia, Canada). While humic acid was obtained from company of Humax Manitoba Ltd (Carberry, Canada), in liquid form.

Screening antibacterial activity of the tested biostimulants against Erwinia carotovora subsp. carotovora and Burkholderia cepacia:

The cup plate method was used to determine the antibacterial activity of Chito, SW and HA against Ecc and Bc. One hundred micro litter of each biostimulant solution was placed in wells centrally made in nutrient agar (NA) containing plates seeded with Ecc and Bc, separately. Plates were incubated at $28^{\circ} \mathrm{C}$ for $24 \mathrm{~h}$, and the diameter of inhibition zone was determined.

\section{In vivo experiments:}

Pot experiment:

The pot experiment was conducted to study the effect of the tested biostimulants (Chito, SW and HA) on controlling onion bacterial rot diseases under artificial inoculation condition. Onion transplants of Giza red cultivar were divided into four groups and their root systems were soaked overnight in the different treatments; Chito at $0.1 \%, \mathrm{SW}$ at $2000 \mathrm{ppm}, \mathrm{HA}$ at $1000 \mathrm{ppm}$ (the candidate concentration of each material was selected according to previous preliminary experiments) and water treatment as a control separately, then air dried. Plastic pots of $17 \mathrm{~cm}$ diameter containing clay: sandy soil mixture $(2: 1)$, were planted with the different seedlings of onion transplants, two transplants per pots. All the suitable cultural practices were carried out through the growing period. Two months after planting, a second spray of each biostimulant was made. One month before the harvest, onion groups were inoculated with liquid bacterial cultures of rot pathogens $(100 \mathrm{ml}$ of the bacterial culture, $10^{6} \mathrm{cfu} / \mathrm{ml}$ were poured in the soil of each pot), each in subgroup as follow:1) inoculated with Ecc, 2) inoculated with Bc and 3) treated with water as control. Onion was harvested after four months from planting (when $50 \%$ of the onion necks fallen down). Then onion was leaved in the open air for two weeks before being stored.

\section{Field experiment:}

This experiment was carried out at Dakahlyia Governorate, Egypt in a field naturally infected with the bacterial rot pathogens to investigate the role of Chito, SW and HA in controlling onion bacterial rot. The experimentation area contained 16 plots $\left(6.5 \mathrm{~m} \times 5 \mathrm{~m}^{2}\right.$ each). Red onion transplants roots (cv. Giza) were soaked in different treatments of Chito at $0.1 \%$, SW at 2000 ppm, HA at 1000 ppm (concentration of each material was selected according to previous preliminary experiments) and water as control. Planting of different treatments was made in the field plots, to make complete randomized design, with four replicates for each treatment. Two months after planting, all the treatments were applied for a second 
time by spraying the onion plants, downward until the soil. All the suitable cultural practices were carried out through the growing period. Onion was harvested four months after planting (when $50 \%$ of the onion necks collapsed). Then crop was kept in open air for two weeks before being stored in the same experimentation pattern.

Preharvest estimations:

One month after planting the photosynthetic pigments were estimated for grown onion in the $3^{\text {rd }}$ upper leaf according to Lichtenthaler and Wellburn (1985). Furthermore, some foliar growth parameters as number and length of leaves were determined in both pots and field grown onions.

Postharvest determinations:

Total phenols content; was determined using Folin-Ciocalteau reagent according to the method of Singleton and Rossi (1965), anthocyanin was assessed following the method of Mancinelli et al. (1975). Total soluble solids; were determined using hand refractometer as described by Andersen (2000). Lipid peroxidation; was determined by the method of Shao et al. (2005) and electrolyte leakage; was estimated according to Goncalves et al. (2007) using an electrical conductivity meter.

Bacterial rot incidence was estimated for both pots and field grown onion after $3,6,8$ and 10 months from the beginning of storage.

\section{Statistical analysis:}

Data were statistically analyzed with CoStat software (Anonymous, 2005). Data were first subjected to analysis of variance (ANOVA), then the multiple comparisons among means were made using new multiple range test at $P \quad \$ 0.05$.

\section{R e s u l t s}

Antibacterial activity of biostimulants against Erwinia carotovora subsp. carotovora and Burkholderia cepacia:

Chitosan (Chito), seaweed extract (SW) and humic acid (HA) had no antibacterial activity against Ecc and Bc where the diameter of inhibition zone was recorded as zero in all cases.

In vivo experiments:

Pot experiment:

Preharvest estimations:

Data in Table 1 showed that, Chito, SW and HA treatments increased the photosynthetic pigments concentration in onion plants compared to the untreated control plants. SW exhibited the best results in this regards hence it significantly increased chlorophyll A (Chl. A), chlorophyll B (Chl. B) and total carotenoids. Moreover, application of HA significantly increased Chl. A and Chl. B concentration in onion leaves as compared with untreated control plants. It was also observed that growth parameters, as leaves number per plant and leaves length, responded positively and significantly to the application of the biostimulants as compared with the control plants. Maximum leaves number per plant (9) was observed in the treatment of Chito and HA and maximum leaves length $(51 \mathrm{~cm})$ was observed in SW as compared with control plants.

Egypt. J. Phytopathol., Vol. 43, No. 1-2 (2015) 
Table 1. Photosynthetic pigments concentration in the $3^{\text {rd }}$ upper onion leaves and plant growth as affected by biostimulants application under artificial inoculation condition in the pot experiment

\begin{tabular}{|l|c|c|c|l|c|}
\hline \multirow{2}{*}{ Treatment* } & \multicolumn{3}{|c|}{ Photosynthetic pigments content** } & \multicolumn{2}{|l|}{ Foliar growth parameters } \\
\cline { 2 - 6 } & $\begin{array}{c}\text { Chl. A } \\
(\mathrm{g} / \mathrm{gm})\end{array}$ & $\begin{array}{c}\text { Chl. B } \\
(\mathrm{g} / \mathrm{gm})\end{array}$ & $\begin{array}{c}\text { Total carotenoids } \\
(\mathrm{g} / \mathrm{gm})\end{array}$ & $\begin{array}{c}\text { No. of } \\
\text { leaves }\end{array}$ & $\begin{array}{c}\text { Length of } \\
\text { leaves }(\mathrm{cm})\end{array}$ \\
\hline Chito & $687.6 \mathrm{~b}$ & $410.4 \mathrm{~b}$ & $494.1 \mathrm{~b}$ & $9 \mathrm{a}$ & $45.5 \mathrm{~b}$ \\
\hline SW & $752.0 \mathrm{a}$ & $544.5 \mathrm{a}$ & $570.1 \mathrm{a}$ & $8 \mathrm{ab}$ & $51.0 \mathrm{a}$ \\
\hline HA & $743.7 \mathrm{a}$ & $567.3 \mathrm{a}$ & $444.4 \mathrm{c}$ & $9 \mathrm{a}$ & $46.5 \mathrm{~b}$ \\
\hline Control & $654.7 \mathrm{c}$ & $355.5 \mathrm{~b}$ & $460.8 \mathrm{bc}$ & $7 \mathrm{~b}$ & $34.5 \mathrm{c}$ \\
\hline
\end{tabular}

* Chito= chitosan, $\mathrm{SW}=$ seaweed extract and $\mathrm{HA}=$ humic acid.

** Chl. A= chlorophyll A and Chl. B= chlorophyll

- Values within a column followed by the same letters are not significantly different according to CoStat software at $\mathrm{p}<0.05$. Values are means of six replicates.

Postharvest estimations:

Data in Table 2 showed that application of biostimulants decreased the disease incidence (DI) caused by Ecc and Bc three after storage of the pots grown onions. Chitosan exhibited promising results in this regard followed by SW and HA, thus the mean DI (DI mean of infected onion) was recorded as zero, 9.55 for Ecc and $19.09 \%$ for $\mathrm{Bc}$, respectively. Furthermore the disease incidence was zero when recorded after six, eight and ten months from storage.

Table 2. Bacterial rot incidence after three months from storage of pots grown onion bulbs as affected by the application of biostimulants

\begin{tabular}{|l|c|c|c|}
\hline $\begin{array}{c}\text { Treatment } * \\
\text { (Biostimulant) }\end{array}$ & $\begin{array}{c}\text { DI of onion ** } \\
\text { infected with Ecc (\%) }\end{array}$ & $\begin{array}{c}\text { DI of onion } \\
\text { infected with Bc }(\%)\end{array}$ & $\begin{array}{c}\text { Mean DI } \\
(\%)\end{array}$ \\
\hline Chito & 0 & 0 & 0.0 \\
\hline SW & 9.1 & 10 & 9.5 \\
\hline HA & 18.2 & 20 & 19.1 \\
\hline Control & 20 & 33.3 & 26.7 \\
\hline
\end{tabular}

* As described in footnote of Table (1).

** DI= Disease incidence.

Field experiment:

Preharvest determinations:

Data in Table 3 indicated that the used biostimulants significantly increased the photosynthetic pigments Chl. A, Chl. B and carotenoids. HA in proven superior in this regard. It was also noticed an increase in the number of leaves, whereas the length of leaves was significantly increased by all treatments. 
Table 3. Photosynthetic pigments concentration in the $3^{\text {rd }}$ upper onion leaves and plant growth as affected by biostimulants application in the field experiment

\begin{tabular}{|c|c|c|c|c|c|}
\hline \multirow{2}{*}{$\begin{array}{c}\text { Treatment } * \\
\text { Biostimulant })\end{array}$} & \multicolumn{3}{|c|}{ Photosynthetic pigments ** } & Foliar growth parameters \\
\cline { 2 - 6 } & $\begin{array}{c}\text { Chl. A } \\
\text { g/gm })\end{array}$ & $\begin{array}{c}\text { Chl. B } \\
(\mathrm{g} / \mathrm{gm})\end{array}$ & $\begin{array}{c}\text { Total carotenoids } \\
(\mathrm{g} / \mathrm{gm})\end{array}$ & $\begin{array}{c}\text { No. of } \\
\text { leaves }\end{array}$ & $\begin{array}{c}\text { Length of } \\
\text { leaves (cm) }\end{array}$ \\
\hline Chito & $618.1 \mathrm{~b}$ & $390.9 \mathrm{a}$ & $431.9 \mathrm{~b}$ & $10 \mathrm{a}$ & $59.7 \mathrm{a}$ \\
\hline SW & $684.8 \mathrm{a}$ & $399.5 \mathrm{a}$ & $480.5 \mathrm{a}$ & $10 \mathrm{a}$ & $61.0 \mathrm{a}$ \\
\hline HA & $699.3 \mathrm{a}$ & $406.6 \mathrm{a}$ & $489.2 \mathrm{a}$ & $10 \mathrm{a}$ & $59.0 \mathrm{a}$ \\
\hline Control & $547.4 \mathrm{c}$ & $279.5 \mathrm{~b}$ & $397.8 \mathrm{~b}$ & $10 \mathrm{a}$ & $48.7 \mathrm{~b}$ \\
\hline
\end{tabular}

$* \& * *$ As described in footnote of Table (1).

- Values within a column followed by the same letters are not significantly different according to CoStat software at $\mathrm{p}<0.05$. Values are means of six replicates

Postharvest determinations:

Data in Table 4 pointed to the efficacy of the tested biostimulants total phenols, anthocyanin pigment, total soluble solids (TSS \%), lipid peroxidation and electrolyte leakage percentage (ELP). It is evident that all treatments increased the total phenols significantly in onion bulbs. All similar effect was recognized of the treatments in concern on anthocyanin and it was slightly higher than that of the control. Moreover the TSS \% was increased by Chito and HA treatments. All treatments significantly decreased the malondialdehye (MDA) concentration indicating significant decrease in lipid peroxidation. The ELP decreased by all treatments.

Table 4. Disease resistance indices in onion bulbs after harvest as affected by biostimulants application in the field experiment

\begin{tabular}{|c|c|c|c|c|c|}
\hline $\begin{array}{c}\text { Treatment } * \\
\text { (Biostimulant })\end{array}$ & $\begin{array}{c}\text { Total phenols } \\
(\mathrm{mg} / 100 \mathrm{gm})\end{array}$ & $\begin{array}{c}\text { Anthocyanin } \\
\text { absorbance/ } \\
\mathrm{gm})\end{array}$ & $\begin{array}{c}\text { Total } \\
\text { soluble } \\
\text { solids (\%) }\end{array}$ & $\begin{array}{c}\text { Lipid** } \\
\text { peroxidation } \\
(\mathrm{MDA}= \\
\mathrm{mol} / \mathrm{gm})\end{array}$ & $\begin{array}{c}\text { Electrolyte } \\
\text { leakage (\%) }\end{array}$ \\
\hline Chito & $37.9 \mathrm{a}$ & $0.8 \mathrm{a}$ & $13.2 \mathrm{a}$ & $1.4 \mathrm{~b}$ & $66 \mathrm{a}$ \\
\hline $\mathrm{SW}$ & $35.6 \mathrm{~b}$ & $0.8 \mathrm{a}$ & $12.3 \mathrm{a}$ & $1.6 \mathrm{~b}$ & $62 \mathrm{a}$ \\
\hline HA & $34.3 \mathrm{~b}$ & $0.8 \mathrm{a}$ & $13.2 \mathrm{a}$ & $2.0 \mathrm{~b}$ & $64 \mathrm{a}$ \\
\hline Control & $31.4 \mathrm{c}$ & $0.8 \mathrm{a}$ & $12.5 \mathrm{a}$ & $3.8 \mathrm{a}$ & $69 \mathrm{a}$ \\
\hline
\end{tabular}

* As described in footnote of Table (1).

** MDA= Malondialdehye.

- Values within a column followed by the same letters are not significantly different according to CoStat software at $\mathrm{p}<0.05$. Values are means of six replicates.

Data in Table 5 revealed that three months storage of the field grown onion decreased the DI incidence of the bacterial rot following treatment with Chito, SW and to a significant level HA in case of HA. Significant decrease in DI was detected after six months of storage, of onion bulbs by all treatments. Similar result was obtained eight and ten months after storage. In general; the reduction in DI values was more pronounced throughout storage durations in months. 
Table 5. Bacterial rot disease incidence throughout storage of field grown onion bulbs as affected by the application of biostimulants

\begin{tabular}{|c|c|c|c|c|}
\hline $\begin{array}{c}\text { Treatment } \\
\text { (Biostimulant) }\end{array}$ & $\begin{array}{c}\text { DI after } \\
\text { 3 months }(\%)\end{array}$ & $\begin{array}{c}\text { DI after } \\
6 \text { months }(\%)\end{array}$ & $\begin{array}{c}\text { DI after } \\
8 \text { months }(\%)\end{array}$ & $\begin{array}{c}\text { DI after } \\
\text { 10 months (\%) }\end{array}$ \\
\hline Chito & $12.2 \mathrm{ab}$ & $7.9 \mathrm{~b}$ & $1.3 \mathrm{~b}$ & $0.3 \mathrm{~b}$ \\
\hline SW & $9.7 \mathrm{ab}$ & $6.3 \mathrm{c}$ & $0.8 \mathrm{~b}$ & $0.0 \mathrm{c}$ \\
\hline HA & $7.5 \mathrm{~b}$ & $6.0 \mathrm{c}$ & $1.9 \mathrm{~b}$ & $0.1 \mathrm{bc}$ \\
\hline Control & $16.3 \mathrm{a}$ & $11.6 \mathrm{a}$ & $3.9 \mathrm{a}$ & $0.8 \mathrm{a}$ \\
\hline
\end{tabular}

* As described in footnote of Table (1)

** DI= Disease incidence.

- Values within a column followed by the same letters are not significantly different according to CoStat software at $\mathrm{p}<0.05$. Values are means of six replicates

\section{D i s c us s i o n}

In the present study, three biostimulants were applied to control bacterial rot diseases of onion. Based on several studies, the biostimulants act through enhancing plant growth and inducing plant resistance to pathogens (Jayaraj et al., 2008; El-Ghamry et al., 2009 and Abdel-Mawgoud et al., 2010). In the present study, number and length of onion leaves were responded positively upon the application of Chito, SW and HA as compared with the control plants, this is in agreement with Farouk et al., 2012 who proved the enhancement of tomato plant growth by application of Chito, SW and HA under natural infection of early blight after one hundred days after transplanting. The enhancement of plant growth by the biostimulants may be attributed to their effect on some physiological processes in plant such as ion uptake, cell elongation, cell division, enzymatic activation and protein synthesis (Vick and Zimmerman, 1987). In this concern, Farouk et al., 2012 found that application of Chito, SW and HA significantly increased ions percentage in tomato shoot represented as nitrogen, phosphorous and potassium which are necessary for plant growth and increase in cell permeability (Chen and Aviad, 1990).

The present work indicated that there was a significant increase in the photosynthetic pigments content in onion leaves after treatments with Chito, SW and HA, that may be due to enhancement in the efficacy of the photosynthetic apparatus and the decrease in photophosphorylation rate, usually occurring after infection (Amaresh and Bhatt, 1998). Biostimulants were found to increase potassium content (Farouk et al., 2012), which may increase the number of chloroplasts per cell, number of cells per leaf and consequently leaf area (Taiz and Zeiger, 1991). The role of SW in increasing chlorophyll content was attributed to the presence of betaines in the SW which decrease chlorophyll degradation (Whapham et al., 1993 and Blunden et al., 1997). These results were confirmed in tomato plants by Zodape et al. (2011) and Farouk et al. (2012) and in faba bean by Al-Ghamry et al. (2009). Moreover, the positive effect of biostimulants on reducing disease incidence may be due to their efficacy as Alicitors since localized treatments of plants with biotic or abiotic defense Alicitors can result in localized or systemic responses. Such biostimulants has the ability to inhibit the devAlopment of the bacterial rot diseases in onion 
plants. Among natural Alicitor compounds, chitosan offers a great potential as a biodegradable material that have anti-microbial and alicitation activities (Benhamou, 1996). In addition to its direct antimicrobial activity, chitosan induces a series of defense reactions correlated with enzymatic activities. Chitosan has been shown to increase the production of glucanohydrolases, phenolic compounds and synthesis of specific phytoalexins with antifungal activity and also reduces macerating enzymes such as polygalacturonases and pectin methylestrase (BautistaBaños et al., 2006). In addition, chitosan induces structural barriers around pathogen penetration sites, for example inducing the synthesis of lignin-like material. Due to its ability to form a semipermeable coating, chitosan extends the shelf life of treated fruit and vegetables by minimizing the rate of respiration and reducing water loss (Bautista-Baños et al., 2006). The antioxidant activity of chitosan has also attracted attention (Park et al., 2004). Chitosan can scavenge $\mathrm{OH}$ and $\mathrm{O} 2$ - radicals and has been shown to have DNA-protective properties (Harish Prashanth et al., 2007).

In the current study the preharvest application of chito on onion plants reduced the incidence of bulb rot throughout storage by inducing defense activities as shown by the significant increase in total phenols in onion bulbs upon chitosan application (Table 4), this is in agreement with the results of Liu et al. (2007) who used chitosan for controlling postharvest grey and blue mould diseases of tomato. The same results were confirmed by Al-Hassni et al. (2004) on the date palm after application of chitosan to control Fusarium oxysporum f.sp. albedinis, the causal agent of a major wilt in this crop. Chitosan application on onion was found to reduce the extent of lipid peroxidation and the Alectrolyte leakage (Table 4). This is in harmony with Yang et al. (2009) and Farouk et al. (2012) who reported that application of chitosan suppressed the increase in MDA concentration in plant tissue and the Alectrolyte leakage. The antioxidant properties of chitosan are primarily attributed to its abundant active hydroxyl and amino groups, which react with ROS to form stable and relatively nontoxic macromolecules radicals (Sun et al., 2004 and 2008). The reduction of onion bacterial rot incidence by chitosan is also in accordance with the results of Abd-Al-Kareem et al. (2002) who reported that chitosan treatment induced resistance against late and early blight diseases of potato and Farouk et al. (2012) who used chitosan to control early blight disease in tomato.

Treatment of onion with SW significantly increased the total phenol contents, also significantly reduced the extent of lipid peroxidation and reduced Alectrolyte leakage (Table 4) confirming its Alicitation activity, these results in agreement with that of Jayaraj et al. (2008) who established the reduction of foliar fungal diseases on carrot upon the application of SW. They attributed the disease control in SWtreated plants to the accumulation of higher levels of defense-related gene transcripts and showed higher activities of defense-related enzymes. They involved as wall the effect of higher levels in the total phenolic content and phytoalexin. In this regard, tomato plants treated with SW showed resistance to leaf curl, bacterial wilt and fruit borer by Zodape et al. (2011) and the reduction in the early blight disease by Farouk et al. (2012). Seaweeds are a rich source of antioxidant polyphenols with bactericidal properties (Zhang et al., 2006). The application of Ascophyllum nodosum extract to bentgrass (Agrostis stolonifera) increased SOD activity, which in 
turn significantly decreased dollar spot disease caused by Sclerotinia homoeocarpa (Khan et al., 2009).

The current study demonstrated that HA at $1000 \mathrm{ppm}$ decreased onion bacterial rot incidence throughout storage, the effect may be attributed is the significant increase in level of the total phenolic content and the significant decrease in the lipid peroxidation and Alectrolyte leakage in the HA-treated plants. (Table 4). These results confirm the role of $\mathrm{HA}$ in enhancing the natural resistance of plant against diseases and pests Abd-Al-Kareem et al. (2009) and Farouk et al. (2012) who proved the potentiality of HA in control early blight disease in potato and tomato, respectively. Furthermore, Abd-Al-Kareem (2007) reported that bean plants treated with humic acid induced resistance against root rot and Alternaria leaf spot in addition to increased bean yield under field conditions.

In conclusion, the tested biostimulants (chitosan, seaweed extract and humic acid) in this study proved to have a promising effect in reducing the onion bacterial rot diseases as shown by the potential to stimulate plant defence against diseases enhancement of plant growth. However, further studies are needed to evaluate in depth the protective role and impacts on diseases resistance.

\section{Ref e r e n c e $s$}

Abd-Al-Kareem, F. 2007. Potassium or sodium bicarbonates in combination with Nerol for controlling early blight disease of potato plants under laboratory, greenhouse and field conditions. Egypt. J. Phytopathol., 35: 73- 86.

Abd-Al-Kareem, F.; Abd-Alla, M.A. and Al-Mohamedy, R.S.R. 2002. Induced resistance in potato plants for controlling early blight disease under field condition. Egypt J. Appl. Sci., 17: 51- 66.

Abd-Al-Kareem, F.; Abd-Al-Latif, Faten M. and Fotouh, Y.O. 2009. Integrated treatments between humic acid and sulfur for controlling early blight disease of potato plants under field infection. Res. J. Agric. Biol. Sci. 5(6): 1039-1045.

Abdel-Mawgoud, A.M.R.; Tantaway, A.S.; Hafez, M.M. and Habib, H.A.M. 2010. Seaweed extract improves growth, yield and quality of different water melon hybrids. Res. J. Agric. Biol. Sci., 6(2): 161- 168.

Amaresh, C. and Bhatt, R.K. 1998. Biochemical and physiological response to salicylic acid in reaction to systemic acquired resistance. Photosynthetica, 35(2): 255- 258 .

Andersen, A.B. 2000. Science in Agriculture: Advanced Methods for Sustainable Farming. Acres, USA.

Anonymous, 2005. CoStat Software, Ver. 6.4. 798 Lighthouse Ave. PMB 320 Monterey, CA, USA.

Bautista-Baños, S.; Hernández-Lauzardo, A.N.; VAlázquez-dAlValle, M.G.; Hernández-López, M.; Ait Barka, E.; Bosquez-Molina, E.; Wilson, C.L. 2006. Chitosan as a potential natural compound to control pre and postharvest diseases of horticultural commodities. Crop Prot., 25: 108-118. 
Benhamou, N. 1996. Alicitor-induced plant defence pathways. Trends Plant Sci., 1: $233-240$.

Blunden, G. 1991. Agricultural uses of seaweeds and seaweed extracts. Pages: 66-81. In: Seaweed Resources in Europe: Uses and Potential. M.D Guiry and G. Blunden (eds.). J. Wiley and Sons, Ltd. Chichester, UK.

Blunden, G. and Gordon, S.M. 1986. Betaines and their sulphono analogues in marine algae. Pages: 39-80. In: Progress in Phycological Research. Vol. 4. Round F.E. and Chapman D.J. (eds). Biopress Ltd., Bristol, UK.

Blunden, G.; Jenkins, T.; Liu, Y. 1997. Enhanced leaf chlorophyll levels in plants treated with seaweed extract. J. Appl. Phycol., 8: 535- 543.

Canellas, L.P.; Olivares, F.L.; Okorokova-Facanha, A.L. and Facanha, A.R. 2002. Humic acids isolated from earthworm compost enhance root Elongation, lateral root emergence and plasma membrane H-ATPase activity in maize roots. Plant Physiol., 130: 1951-1957.

Chaput, J. 1995. Identification of diseases and disorders of onions. Minist. Agric., Food and Rural Affairs Ontario, Canada. http://www.omafra.gov.on.ca/english/ crops/facts/95-063.htm

Chen, Y. and Aviad T. 1990. Effects of humic substances on plant growth. Pages: 161-186. In: Humic Substances in Soil and Crop Sciences. McCarthy (ed.). Amer. Soc. Agron. and Soil Sci., Madison, Wis.

Chen, Y.; Clapp, C.E. and Magen, H. 2004a. Mechanisms of plant growth stimulation by humic substances: The role of organo-iron complexes. Soil Sci. Plant Nutr., 50: 1089-1095.

Chen, Y.; de Nobili, M. and Aviad, T. 2004b. Stimulatory effect of humic substances on plant growth. Page: 103. In: Soil Organic Matter in Sustainable Agriculture. Magdoft, F. and Ray, R. (eds.). CRC Press, Washington DC., USA.

Al-Hassni, M.; Al Hadrami, A.; Daayf, F. and Barak, E.A. 2004. Chitosan, antifungal product against Fusarium oxysporum f.sp. albedinis and Alicitor of defence reactions in date palm roots. Phytopathol. Mediterr., 43: 195-204.

Al-Ghamry, A.M.; Abd Al-Hai, K.M. and Ghoneem, K.M. 2009. Amino and humic acids promote growth, yield and disease resistance of faba bean cultivated in clayey soil. Aus. J. Basics Applied Sci., 3(2): 731- 739.

Farouk, S.; Ghoneem, K.M. and Ali A.A. 2008. Induction and expression of systematic resistance to downy mildew disease in cucumber plant by Alicitors. Egypt. J. Phytopathol., 36: 95- 111.

Farouk, S.; Youssef, S.A. and Ali, A.A. 2012. Exploitation of biostimulatants and vitamins as an alternative strategy to control early blight of tomato plants. Asian J. Plant Sci.., 11(1): 36- 43.

Goncalves, J.F.; Becker, A.G.; Crgnelutti, D.; Tabaldi, L.A.; Pereira, L.B.; Battisti, V.; Spanevello, R.M.; Morsch, V.M.; Nicoloso, F.T. and Schetinger, M.R.C. 2007. Cadmium toxicity causes oxidative stress and induces response of the antioxidant system in cucumber seedlings. Braz. J. Plant Physiol., 13(3): 223- 232.

Egypt. J. Phytopathol., Vol. 43, No. 1-2 (2015) 
Harish Prashanth, K.V.; Dharmesh, S.M.; Jagannatha, Rao, K.S. and Tharanathan, R.N. 2007. Free radical-induced chitosan depolymerized products protect calf thymus DNA from oxidative damage. Carbohydr. Res., 342:190- 195.

Jayaraj, J.; Wan, A.; Rahman, M. and Punja, Z.K. 2008. Seaweed extract reduces foliar fungal diseases on carrot. Crop Protec., 27: 1360- 1366.

Khan, W.; Rayirath, U.P.; Subramanian, S.; Jithesh, M.N.; Rayorath, P.; Hodges, D. M.; Critchley, A.T.; Craigie, J.S.; Norrie, J.; Craigie, J.S. and Prithiviraj, B. 2009. Seaweed extracts as biostimulants of plant growth and devAlopment. J. Plant Growth Regul., 28: 386- 399.

Lichtenthaler, H.K. and Wellburn, A.R. 1985. Determination of total carotenoids and chlorophylls A and B of leaf in different solvents. Biol. Soc. Trans., 11: $591-592$.

Liu, J.; Tian, S.; Meng, X. and Xu, Y. 2007. Effects of chitosan on control of postharvest diseases and physiological responses of tomato fruit. Postharvest Biol. Technol., 44: 300- 306.

Mancinelli, A.L., Yang, C.P. H.; Lindquist, P.; Anderson, O.R. and Rabino I. 1975. Photocontrol of anthocyanin synthesis. III. The action of streptomycin on the synthesis of chlorophyll and anthocyanin. Plant Physiol., 55: 251- 257.

Mansour, F.A.; Abdallah, M.E.; Haroun, S.A.; Gomah, A.A. and Badr, H.H. 2011. Occurrence and prevalence of the bacterial onion bulb rot pathogens in Egypt. $J$. Plant Prot. Pathol., 2: 239- 247.

McNab, A. 2004. Vegetable Disease Identification. Pennsylvania State Website. Pennsylvania. USA.

Norrie, J. and Keathley, J.P. 2006. Benefits of Ascophyllum nodosum marine-plant extract applications to 'Thompson seedless' grape production. Acta Hort., 727: 243- 247.

Park, P.J.; Je, J.Y and Kim, S.K. 2004. Free radical scavenging activities of differently deacetylated chitosans using an ESR spectrometer. Carbohydr. Polym., 55: 17- 22.

Schwartz, H. F. and Gent, D.H. 2004. Onion, Diseases, Slippery and Sour Skin. High Plains IPM Guide. Nebraska, USA..

Shao, H.B.; Liang, Z.S.; Shao, M.A. and Wang, B.C. 2005. Changes of antioxidative enzymes and membrane peroxidation for soil water deficits among 10 wheat genotypes at seedling stage. Colloids surfaces B. Biointerfaces, 42(2): 107- 113 .

Sharathchandra, R.G.; Niranjan Raj, S.; Shetty, N.P.; Amruthesh, K.N. and Shekar Shetty, H. 2004. A chitosan formulation Alexa TM induces downy mildew disease resistance and growth promotion in pearl millet. Crop Prot., 23: 881-888.

Sheikha, S.A. and Al-Malki, F.M. 2011. Growth and chlorophyll responses of bean plants to the chitosan applications. Eur. J. Sci. Res., 50(1): 124- 134. 
Singleton, V.L. and Rossi, J.A. 1965. Colorimetry of total phenolics with phosphomolybdic-phosphotungstic acid reagents. Am. J. Enol Viticulture 16:144- 158.

Sun, T.; Xie, W.M. and XU, P.X. 2004. Superoxide anion scavenging activity of graft chitosan derivatives. Carb. Polym., 58: 379- 382.

Sun, T.; Yao, Q.; Zhou, D. and Mao, F. 2008. Antioxidant activity of N-carboxymethyl chitosan oligosaccharides. Bioorg. Med. Chem. Lett., 18: 5774- 5776.

Taiz, L. and Zeiger, E. 1991. Cytokinins. Pages: 452-472. In: Plant Physiology. Taiz, L. and Zeiger, E. (eds.). Benjamin/Cummings, Redwood, CA., USA.

Ugarte, R.A.; Sharp, G. and Moore, B. 2006. Changes in the brown seaweed Ascophyllum nodosum (L.) Le Jol. Plant morphology and biomass produced by cutter rake harvests in southern New Brunswick, Canada. J. Appl. Phycol., 18: $351-359$.

Vick, B.A. and Zimmerman, D.G. 1987. Pathways of fatty acid hydroperoxide metabolism in spinach leaf chloroplasts. Plant Physiol., 85: 1073-1078.

Whapham, C. A.; Blunden, G.; Jenkins, T. and Hankins, S.D. 1993. Significance of betaines in the increased chlorophyll content of plants treated with seaweed extract. J. Appl. Phycol., 5: 231-234.

Yang, F.; Hu, J.; Li, J.; Wu, X. and Qian, Y. 2009. Chitosan enhances leaf membrane stability and antioxidants enzyme activities in apple seedlings under drought stress. Plant Growth Regul., 58: 131- 136.

Zhang, Q.; Zhang, J.; Shen, J.; Silva, A.; Dennis, D.A.; Barrow, C.J. 2006. A simple 96-wAll microplate method for estimation of total polyphenol content in seaweeds. J. Appl. Phycol., 18: 445- 450.

Zhang, X. and Schmidt, R.E. 1997. The impact of growth regulators on the $\alpha$-tocopherol status in water-stressed Poa pratensis L. Internat. Turfgrass Res. J., 8: 1364 -1373.

Zodape, S.T.; Gupta, A.; Bhandari, S.C.; Rawat, U.S.; Chaudhary, D.R.; Eswaran, K. and Chikara, J. 2011. Foliar application of seaweed sap as biostimulant for enhancement of yield and quality of tomato (Lycopersicon esculentum Mill.). J. Sci. Industrial Res., 70: 215- 219.

Zodape, S.T.; Kawarkhe, V.J.; Patolia, J.S. and Warade, A.D. 2008. Effect of liquid seaweed fertilizer on yield and quality of okra (Abelmoschus esculentus L.). J. Sci. Industrial Res., 67: 1115- 1117.

(Received 22/04/2015; in revised form 26/05/2015) 


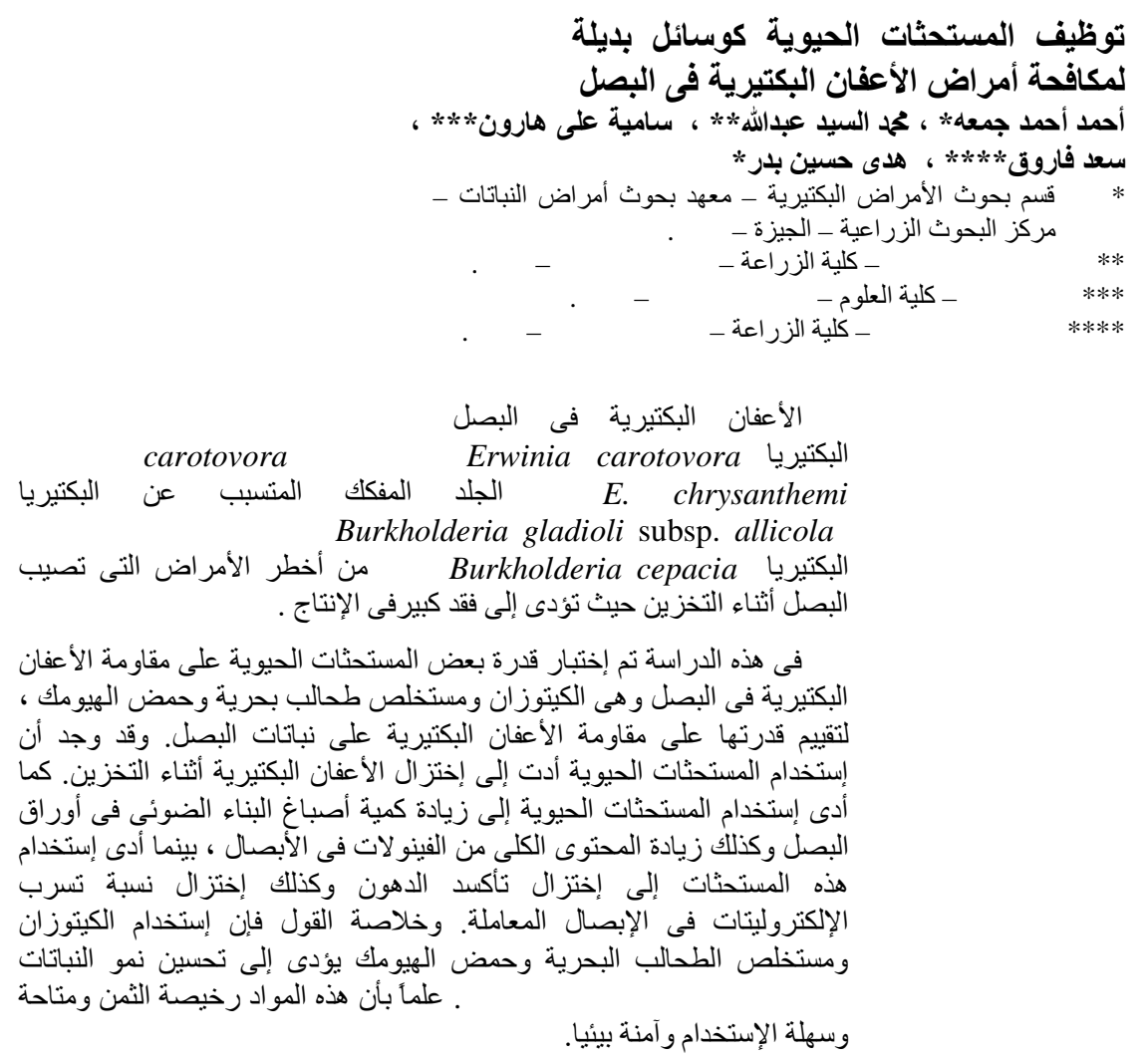

